Each paper was followed by critical discussion. This emphasized the importance of considering the social and political relevance of problems selected for study, while upholding the principle of the freedom of scholatly research.

The second conference of the Association is planned to be held from 17 to I9 July 1970; an account of the proceedings will be given in a later number of Africa.

\title{
U.S. Research in Progress
}

AMong research projects in anthropology, sociology and linguistics listed in the FebruaryMarch 1970 issue of African Studies Newsletter (U.S.A.) are the following:

Angola

Carmen Diane Christensen (Columbia): history of Ovimbundu x 700-1880.

Cameroon

Richard G. Dillon (Pennsylvania): ecology and social organization in the Cameroon. Igor Kopytoff (Pennsylvania): ethnography of the Aghem and Wum, West Cameroon.

\section{ETHIOPIA}

Michael D. Quam (Indiana): changing local-level politics among the Afar.

Charles $A$. Ferguson (Stanford): the use of Arabic as a lingua frança by certain segments of the Ethiopian population.

\section{GHANA}

Joan M. Rosenbloom (Northwestern): Ewe communities in Kumasi and Tamale.

H. C. Weinand (Wisconsin): internal trade marketing in Ghana.

N. O. Oddon (Northwestern): Islamic education in Yendi.

James W. Brown (Wisconsin): social history of Kumasi $1900-40$.

Peter Der (Northwestern): the linguistic relationship between Dagbani and Dagaare.

Paul Kotey (Howard): Ga grammar and Twi grammar.

William Leben (Northwestern): spoken Hausa and the tonal system in Dagbani.

Augustine Seyere (Northwestern): Dagomba traditional religion.

M. G. Asnes (Rochester): women in group participation in Madina.

Robert Pozen (Harvard): the sociology of new towns in Ghana.

Dorothy Lee Vellenga (Columbia): attempts to change family laws in Ghana and the Ivory Coast.

\section{KENYA}

Stephen M. Fjellman (Stanford): decision-making among the Kamba.

Robert Manners (Brandeis): the impact of colonialism in Kenya.

Thomas Weisner (Harvard): urbanization and family change in Nairobi.

Malcolm D. Valentine (UCLA): Luo society 1900-63.

LIBERIA

James W. Beckman (University of California, Irvine): economic change and cultural continuity among the Kpelle.

John H. Gay (Richmond College, Earlham, Indiana): chiefdom and clan maps of western Liberia (with Svend Holsoe and Warren D'Azevedo).

W. Penn Handwerker (Oregon): inter-tribal variation and change among the Bassa.

\section{MADAGASCAR}

Karl L. Eggert (UCLA): decision-making among the Mahafaly. 


\section{Morocco}

Thomas W. Ditcher (Chicago) : education and social change in a Moroccan town.

Daisy Kokot (Yale): conflict and change in Moroccan village law.

Kevin D. Kokot (Yale): entrepreneurial activity in Moroccan market-places.

James T. Cooke (Mississippi): the colonial period in Algeria and in Morocco.

NIGER

Ralph Faulkingham (Wayne and Michigan State) : political activity in a rural Hausa village.

NigerIA

John Pemberton III (Amherst): ritual and sacral change among the Yoruba.

SENEGAL

Raymond Betts (Grinnell College): the problem of the Medina in the urban planning of Dakar.

UGANDA

Gary P. Ferraro (Syracuse): kinship relations in an East African urban area.

\section{International African Institute: Reprints}

MANY of the Institute's earlier publications have been or are in the process of being reprinted by the Oxford University Press or by publishers specializing in Africana. The following have recently been reprinted by the Clarendon Press, Oxford:

Tales Told in Togoland, by A. W. Cardinall (1931). 70s.

The Pastoral Fulbe Family in Gwandu, by C. Edward Hopen (1958). 60s.

Nuer Law, by P. P. Howell (1954). 75s.

The Premise of Inequality in Ruanda, by J. J. Maquet (1961). 65s.

Rituals of Kinship among the Nyakyusa, by Monica Wilson (1957). 90s.

Communal Rituals of the Nyakywsa, by Monica Wilson (1959). 755 .

Titles forthcoming from Frank Cass include:

A Tribal Survey of Mongalla Province, by L. F. Nalder (1937).

Nuer Customs and Folklore, by Ray Huffman (1931).

Customary Law of the Haya Tribe, by Hans Cory and M. M. Hartnoll (1945).

Sukuma Law and Custom, by Hans Cory (1953).

The Ngoni of Nyasaland, by Margaret Read (1956).

The Oxford University Press is reprinting for the Institute for publication in the autumn a revised edition of Chopi Musicians, by Hugh Tracey, which will include a new introduction by Dr. Tracey and revised musical transcriptions by his son, Andrew Tracey, and the late Günter Wagner's two-volume study of the Bantu of North Kavirondo. The latter will appear in one volume under the revised title The Bantu of Western Kenya.

Languages of West Africa, by Diedrich Westermann and M. A. Bryan, has been reprinted by Dawsons with the addition of a comprehensive supplementary bibliography compiled by Professor D. W. Arnott and others.

A number of out-of-print Parts of the Ethnographic Survey of Africa have been reprinted with supplementary bibliographies. Details of these and of all the Institute's publications may be obtained from the Secretary. 